[RETRACTED ARTICLE]: Anti-citrullinated peptide antibodies and rheumatoid factor in Sudanese patients with Leishmania donovani infection

\title{
[ARTIGO RETRATADO]: Anticorpos antipeptídeos citrulinados e fator reumatoide em pacientes sudaneses com infecção por Leishmania donovani
}

ABSTRACT: The Brazilian Journal of Rheumatology (Revista Brasileira de Reumatologia) decided to retract the manuscript entitled Ahlin E, Elshafei A, Nur M, El Safi SH, Johan R, Elghazali G. Anti-citrullinated peptide antibodies and rheumatoid factor in Sudanese patients with Leishmania donovani infection. Rev Bras Reumatol. 2011 Dec;51(6):57986.English, Portuguese.

The reasons point out were:

(1)Author Elghazali G did not take part in production the data for the paper and has never been a co-author on any version of the manuscript.

(2) A paper with very similar content, which was part of the PhD thesis of author Ahlin E (first author), was accepted for another journal.

(3) The figures in the paper published in this journal $X$ were identical to the figures in author Ahlin E's PhD thesis.

(4) The name of author Johan Ronnelid was misspelt in the paper published in our journal (RBR) .

The authors E Ahlin, A Elshafei, M Nur and J Ronnelid agreed with the retraction according to the reasons (1, 2, 3, and 4). G Elghazali did not agree and SH El Safi did not respond to our requests.

The retraction is formally approved by the Editors of Revista Brasileira de Reumatologia

Sao Paulo, April 8, 2014

Editors of the Brazilian journal of Rheumatology 


\title{
Anti-citrullinated peptide antibodies and rheumatoid factor in Sudanese patients with Leishmania donovani infection.
}

\author{
Erik Ahlin, $\mathrm{PhD}^{1}$, Amir Elshafei ${ }^{2}$, Musa Nur ${ }^{3}$, \\ Sayda Hassan El Safi ${ }^{4}$, Ronnelid Johan ${ }^{5}$, Gehad Elghazali 6
}

ABSTRACT

Objective: The present study evaluated the presence of anti-cyclic citrullinated peptides antibodies (anti-CCP), rheumatoid factor (RF), and circulating immune complexes (CIC) in Sudanese patients infeeted with the Leishmania donovani parasite. Patients and methods: Sera were collected from Leishmania infected patients ( $=116)$ and healthy Sudanese $(\mathrm{n}=93)$. Nineteen Sudanese anti-CCP+ RA patients were included as positive controls. Levels of CIC and anti-CCP were measured by ELISA. Control plate with cyclic control peptides containing arginin instead of citrulline was used to evaluate citrulline specific reactivity. Results: Among Leishmania-infected patients and anti-CCP+ RA patients, most were RF positive $(86 \%)$, while the frequency of CIC positivity was higher among visceral leishmaniasis (VL) patients (VL 38\%; anti-CCP+ RA 24\%). When anti-CCP reactivity was analysed, $12 \%$ of 4 patients were found to be positive. The levels of anti-CCP among VL patients correlated well with the CIC levels found ( $\mathrm{r}-0.65, \mathrm{P}<0.0001)$. In RA group, no association was found between CIC and anti-CCP. The possibility that anti-CCP positivity was due to cross reactions with CIC was experimentally ruled out. Contrary to what was seen in Sudanese RA sera, the CCP reactivity was not restricted to citrulline but reacted equally well with the arginine control peptide Conclusion: The finding that CCP reactivity was not restricted to citrulline argues that this is more an effect of extensive infammation and immune activation than a sign of shared pathogenic characteristics with anti-CCP arthritis. O findings stress the importance to interpret a positive CCP test carefully when evaluated in non-rheumatic conditions or in areas where such infections predominate.

Keywords: rheumatoid factor Leishmaniadonovani, antigen-antibody complex.

\section{INTRODUCTION}

Leishmaniasis is a parastic Aisease caused by the Leishmania parasite. The disease has different types which includes: visceral leishman asis (NV), post-kala-azar dermal leishmaniasis (PKDL), cutaneous leishmaniasis, mucocutaneous leishmaniasis, and viscerotropic leishmaniasis. VL, also known as kala-azar, is caused by the Leishmania donovani parasite and is associated with an immunopathology characterised by a strong humoral immune response with high production of anti-leishmanial antibodies, circulating immune complexes (CIC), and polyclonal activation of B-lymphocytes.
PKDL is a complication of VL, characterized by severe rashes most often in young patients who have recovered from VL and are otherwise well. Rheumatoid arthritis (RA) is a common systemic autoimmune disorder affecting mainly women $40-60$ years old. The most prominent symptom is chronic inflammation of the joints, although extra-articular manifestations are also seen.

Rheumatoid factors (RFs) are auto-antibodies that are reactive with the Fc-portion of IgG. The classic RF is an IgM antibody with reactivity against $\operatorname{IgG}-\mathrm{Fc}$, but $\operatorname{IgA}$ and $\operatorname{IgG} \mathrm{RF}$ can also be found. RFs are detected in sera of most patients with RA. ${ }^{1}$ Although the presence of RFs in RA patients correlates

Received on 04/09/2011. Approved on 08/30/2011. Authors declare no conflict of interests. Financial Support: Institutional (university).

1. Msc - Immunobiology, Clinical Immunology Unit, Uppsala University, Uppsala, Sweden

2. Bachelor of Medicine - Hematology Laboratory of Pathology and Microbiology, Alribat Hospital, Khartoum, Sudan

3. Rheumatologist - Consultant, Unit of Rheumatology, Alribat University Hospital, Khartoum, Sudan

4. Professor of Immunology - Consultant, Department of Microbiology and Parasitology, Faculty of Medicine, University of Khartoum, Sudan

5. Associate Professor of Immunology - Consultant, Clinical Immunology Unit, Uppsala University, Uppsala, Sweden.

6. Professor of Immunology - Senior Consultant, University of Shendi, Shendi, Sudan; and King Fahad Medical City, Riyadh, Kingdom of Saudi Arabia

Correspondence to: Gehad Elghazali. King Fahad Medical City, Riyadh 11525, Saudi Arabia. E-mail: gelghazali@gmail.com 
with more active disease, RF has a low specificity as a disease marker for RA when compared to controls with other rheumatic diseases and infections..$^{2-5}$

Immune complexes (ICs) exert central functions in RAinflammation by stimulation of monocytes/macrophage-mediated production of cytokines in rheumatic diseases and are also implied in the induction of RF in RA. ${ }^{6}$ Association between IC and $\mathrm{RF}$ has also been demonstrated in other rheumatic diseases as well as in infectious diseases. ${ }^{7,8} \mathrm{RF}$ production in VL was reported years ago, ${ }^{9}$ and $\mathrm{CIC}$ are also found to be increased in chronic leishmaniasis and many other tropical parasitic diseases. ${ }^{10-15} \mathrm{We}$ have earlier demonstrated that isolated IC from Leishmania-infected patients induces both pro-inflammatory and immunosuppressive cytokines. Furthermore, levels of C1qbinding IC in serum were closely correlated to the IC-induced cytokine levels. ${ }^{16}$

Anti-citrullinated proteins and/or peptides antibodies (ACPA) have come forward as specific serological markers for RA, with higher diagnostic specificity for RA but with similar sensitivity to RF and the former test is clearly superior in specific scenarios. The event of citrullination of proteins and peptides occurs naturally during inflammation and is a post-translational modification of arginine by deamination. ${ }^{17}$ Antibodie agan st several different citrullinated proteins have been associated with RA, and anti-CCP positive RA patients develop moresevere clinical manifestations than anti-CCP negative pat ents. ${ }^{18,19}$ Anti-CCP reactivity in RA patients has been associated with several genetic predisposing factors notably the "shared epitope" HLA alleles, but also with environmental factors such as smoking. ${ }^{20}$ The presence of anti-CP has also been demonstrated in a number of infectious diseases, e.g., pulmonary tuberculosis, hepatitis infection, and type 1 autoimmune hepatitis. ${ }^{21-25}$ Importanty, anti CCP positivity seen in nonRA disease sera seems not to be always citrulline-dependent as demonstrated by Vannini et al. ${ }^{24}$ Due to our interest in the ACPA response in $\mathrm{R}^{18,26,27}$ and our previous studies on IC mediated inflammation in Leishmania infected patients, ${ }^{16}$ here we aim to investigate ACPA, RF, and CIC in African patients also infected with $L$. donovani.

\section{PATIENTS AND METHODS}

\section{Patients and sampling}

Serum samples were collected from $74 \mathrm{VL}$ patients (mean age 23 years, range 3-73, female/male ratio 25/48), $42 \mathrm{PKDL}$ patients (mean age 11 years, range 4-27, female/male ratio 14/25), 93 healthy Sudanese controls (mean age 23 years, range 3-54, female/male ratio 26/67). VL- and PKDL-patients were from Tabarakalla rural hospital in Gadarif state, along the lower Atbara River in Gallab Province, Eastern Sudan. This area is located $70 \mathrm{~km}$ southeast from the Gadarif town. It is endemic for L. donovani and the main vector in this area is Phlebotomus orientalis.$^{28}$ Patients enrolled in the study mainly came from the Tabarakalla and Barbar Elfogara villages, endemic areas with a high prevalence of both VL and PKDL, A detailed clinical history was obtained, including tribe, residence, occupation, marital status, medical treatment, abdomina pain, yomiting, nausea, previous history of bleeding tendency, urinary tract infection and insect bites, and family history of $L$, hypertension, or diabetes mellitus. Particular emphasis was given to any previous form of leishmaniasis. Subjects vere questioned about their ethnic and geographic origin and were examined for clinical manifestations of VL. None of the patient reported a family history or any history of illness known to be associated with RA or other systemic autoimmune diseases. A general clinical examination was conducted with special attention to hepatosplenomegaly, enlargement of lymph nodes, and recurrent fever for more than one month. Liver size was measured in the mid clavicular line from the costal margin; the spleen size was assessed by measuring the distance between the costal margin in the anterior axillary line to the tip of the spleen. Lymphadenopathy was classified as "localized" if only found at one site and "generalized" if found at two or more sites. The oral and nasal mucous membranes were examined for evidence of mucosal leishmaniasis. Thick and thin blood films for detection of Plasmodium parasites were examined from all individuals who either had fever, looked ill, or had splenomegaly, and those with positive blood films for malaria were excluded. An inguinal lymph node aspiration was performed on those clinically suspected of having VL (i.e., all individuals with fever for more than two months, left upper quadrant pain, lymphadenopathy, splenomegaly, or wasting). Those with a negative result underwent bone marrow aspiration from the superior posterior iliac crest. The smears were fixed with methanol, stained with Giemsa, and examined using an oil-immersion lens. PKDL was diagnosed on clinical grounds, on the appearance and distribution of rash after treatment in previously diagnosed VL patients. There are no laboratory tests for diagnosing PKDL.

Nineteen RA patients (mean age 45 years, range $22-60$, female/male ratio 17/2) were sampled from a RA cohort from the Rheumatology Unit at Alribat University Hospital where they had been diagnosed by a rheumatologist according to the 1987 American College of Rheumatology (ACR) criteria. ${ }^{29}$ The RA patients were primarily chosen as positive controls in the antiCCP specificity investigation, thus only anti-CCP positive patients were included. Healthy Sudanese controls were recruited from the Tabarakalla rural area and from Alribat University Hospital. For 
the anti-CCP and RF analyses, 100 Swedish healthy controls were used to validate the company-defined reference ranges, whereas a smaller Swedish control group $(n=20)$ were used to verify the cut-off for ELISA measurement of C1q-binding circulating IC. Sera were separated by centrifugation within two hours of collection, and samples were separated and frozen in liquid nitrogen (countryside) or $-70^{\circ} \mathrm{C}$ freezer (Khartoum) within two hours of sampling, stored frozen at $-70^{\circ} \mathrm{C}$ and transported on dry ice to Uppsala, Sweden. Ethical approval for this study was obtained from the Ethics Committee of the Alribat University Hospital, from the Faculty of Medicine of the University of Khartoum, from the Ministry of Health of Gadarif State, and from the Ethics Committee of Uppsala University. Informed consent was obtained from all of the adults who participated in the study. For young children, consent was obtained from their parents.

\section{Measurement of levels of $\mathrm{CIC}$, anti-CCP, and RF}

\section{C1q-binding assay for $\mathrm{CIC}$}

Levels of CIC were measured by a solid-phase C1q assay (Bindazyme C1q binding kit; Binding Site, Birmingham UK). According to the producer of the kit, levels above $10.8 \mathrm{Eq} / \mathrm{mL}$ are regarded as positive. The range of the assa is $1.23-100 \mathrm{Eq} / \mathrm{mL}$.

\section{Anti-CCP}

Anti-CCP was measured using the Immunoscan RAMark 2 assay (Euro-Diagnostica, Malmö, Sweden). Antr-CCP positivity was determined in accordance with producer's unstructions, with $25 \mathrm{U} / \mathrm{mL}$ used as a cut-off. The assay coes not yield quantitative levels below the company-defined cut-off. For that reason we extended the standard curye to obtain values also below $25 \mathrm{U} / \mathrm{mL}$ (extended range 3.126-1600 U/mL). Values above the range of the standard curve were given the value $1600 \mathrm{U} / \mathrm{mL}$.

A control ELIS plate with cyclic peptides containing arginine instead of crtulline in the relevant peptide positions was kindly provided by Jörgen Wieslander at Euro-Diagnostica and was used to evaluate citrulline-specific reactivity. The cutoff value for arginine control was determined arbitrarily by the absorbance corresponding to $25 \mathrm{U} / \mathrm{mL}$ in the standard curve for the citrulline $(\mathrm{CCP})$ variant. Results were then calculated as cut-off index (COI): observed arginine $\mathrm{OD}_{450}$ / citrulline cut-off $\mathrm{OD}_{450}$ according to Vannini et al. ${ }^{24}$

To test if CIC present in the investigated samples influenced anti-CCP reactivity, we adsorbed C1q-binding IC from sera and evaluated CCP reactivity afterwards. Eight anti-CCP+ VL-, four PKDL- and six of the RA patients were tested. Sera were diluted 1:50 and incubated for 2 hours on Clq coated plates (Bindazyme
C1q binding kit; Binding Site). The samples were directly transferred to the CCP plate after incubation and analysed for anti-CCP according to the producer of the anti-CCP testing kit.

\section{Rheumatoid factor}

RF was measured by nephelometry (Immage, Beckman Coulter), and expressed in international units $/ \mathrm{mL}$ (IU/mL), with values $>20 \mathrm{IU} / \mathrm{mL}$ regarded as positive. The analysis was standardized using the NIBSC 64/002 reference serum. The nephelometer does not express quantitative data below $20 \mathrm{IU} / \mathrm{mL}$, and RF negative samples yere given the value $0 \mathrm{IU} / \mathrm{mL}$ when comparing different groups.

\section{Statistics}

The Mann-Yhitney test was used to compare groups. For correlations betwen groups, Pearson correlation test was used. $\mathrm{P}<0.05$ were considered significant.

\section{RESULTS}

\section{Rheumatoid factor}

Among VL patients, $86 \%(64 / 74)$ were RF positive, with a median of $71 \mathrm{IU} / \mathrm{mL}$ among the positive subjects and range 20-1440 IU/mL. For PKDL patients, 69\% (29/42) were positive with a median of $34 \mathrm{IU} / \mathrm{mL}$ and range $20-165 \mathrm{IU} / \mathrm{mL}$. In the anti-CCP positive RA group, 84\% (16/19) were also positive for RF (median $239 \mathrm{IU} / \mathrm{mL}$, range $69-3470 \mathrm{IU} / \mathrm{mL}$ ). Among the Sudanese controls, 11\% (10/93) had RF levels above $20 \mathrm{IU} / \mathrm{mL}$ (median $23 \mathrm{IU} / \mathrm{mL}$, range 20-96 IU/mL). In a cohort of 100 healthy Swedish controls, two were found weakly RF positive (20.4 and $21.6 \mathrm{IU} / \mathrm{mL}$ ).

The VL group had higher RF levels as compared with PKDL patients $(P<0.0001)$. There was no significant difference between anti-CCP+ RA patients and VL patients. However, RA patients had higher levels as compared to PKDL patients $(\mathrm{P}=0.0004)$. All three disease groups had significantly higher RF levels than the healthy Sudanese controls. The results are shown graphically in Figure 1.

\section{Circulating immune complexes}

Levels of CIC were determined in VL, PKDL, and anti-CCP positive RA patients, Sudanese healthy individuals, and in a Swedish control cohort (Figure 2). Among the VL patients, $31 \%(23 / 74)$ had elevated IC levels (median $7 \mathrm{Eq} / \mathrm{mL}$, range $0.0-100.6 \mathrm{Eq} / \mathrm{mL})$, whereas among PKDL patients, 7\% (2/42) had elevated IC levels (median $2.0 \mathrm{Eq} / \mathrm{mL}$, range $0-21 \mathrm{Eq} / \mathrm{mL}$ ). One out of 20 anti-CCP positive RA patients had IC level 


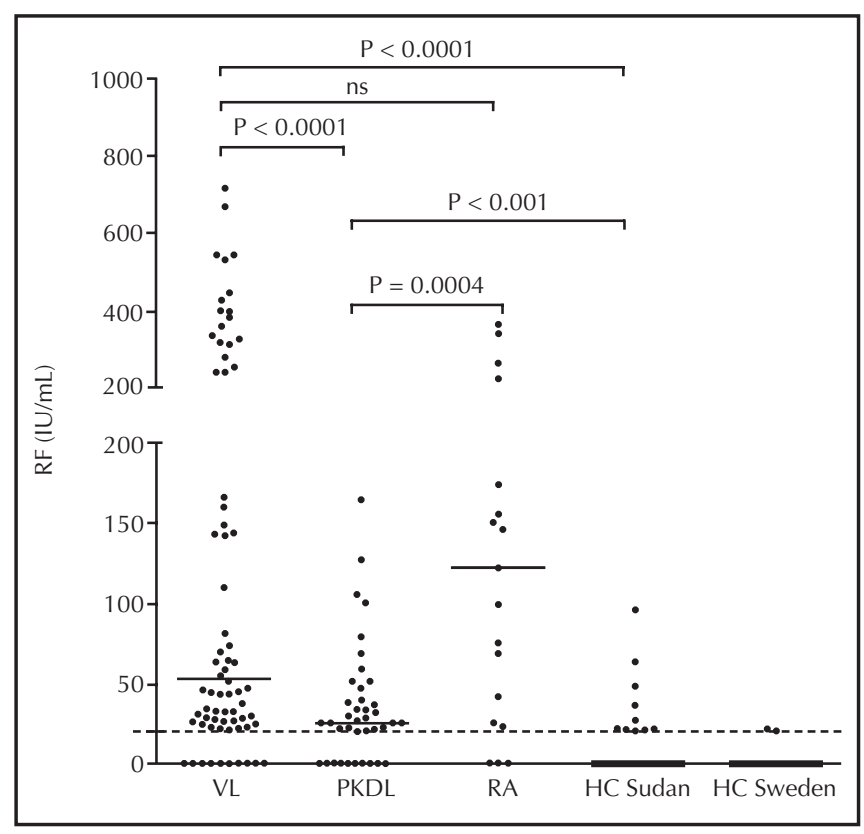

\section{Figure 1}

Levels of RF in the different groups. The dotted line represents the cut-off $(20 \mathrm{IU} / \mathrm{mL})$ for the nephelometer. Solid lines show the median in each group.

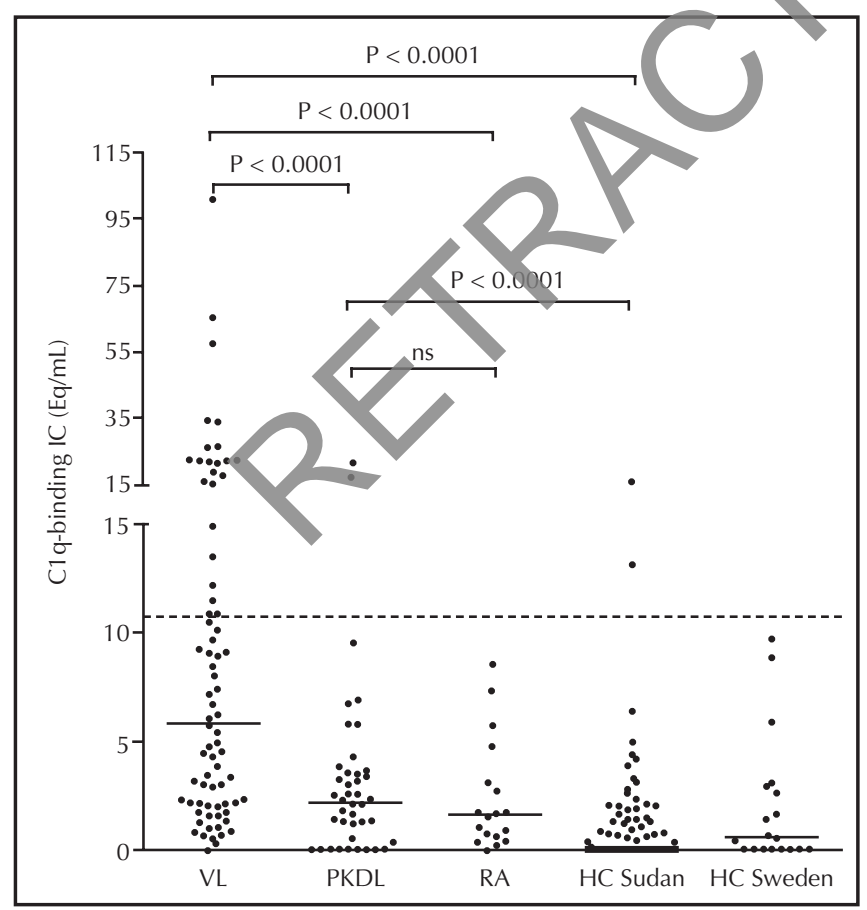

Figure 2

Levels of CIC in the different groups. The dotted line represents the cut-off $(10.8 \mathrm{Eq} / \mathrm{mL})$ as recommended by the producer, and solid lines show the median in each group. above $10.8 \mathrm{Eq} / \mathrm{mL}$, (median $1.5 \mathrm{Eq} / \mathrm{mL}$, range 0-10.8). In the Sudanese control group ( $\mathrm{n}=93)$, two were positive for CIC. In the Swedish control group, all individuals were negative for CIC. The VL patients had significantly higher IC levels than all other investigated groups ( $\mathrm{P}<0.0001$ for all comparisons $)$.

\section{Anti-CCP reactivity}

Among the VL patients, $12 \%(9 / 74)$ were found to be anti-CCP positive (median $30.86 \mathrm{U} / \mathrm{mL}$, range 25 148). Anti-CCP reactivity was also found in $4.2 \%$ of the PKDL patients $(2 / 42,34$ and $95 \mathrm{U} / \mathrm{mL}$ ). Among the ant-CCP positive Sudanese RA patients, anti-CCP levels were much higher: median $1265 \mathrm{U} / \mathrm{mL}$, range $50->1600 \mathrm{U} / \mathrm{mL}$. In the Sudanese healthy control group, one anti-CCP positive was found $(51 \mathrm{U} / \mathrm{mL})$. In the Swedish control group ( $\mathrm{n}=100$ ), three were found positive, two of them in the borderline region (30, 42 and $1643 \mathrm{U} / \mathrm{mL})$. We observed that VL and P $\mathrm{CDL}$ patents exhibited more reactivity to $\mathrm{CCP}$ at levels in-between the lower detection limit of the assay $(3.126 \mathrm{U} / \mathrm{mL})$ and the cut-off $25 \mathrm{U} / \mathrm{mL}$. Median level for the anti-CCP-negative VL patients was $6.7 \mathrm{U} / \mathrm{mL}$ and for the anti-CCP-negative PKDL patientes was $7.9 \mathrm{U} / \mathrm{mL}$. These results diverged from those for the Sudanese healthy control group where samples were either more clearly positive or negative as shown in Figure 3, where the median level for the CCP-negative subjects was $5.1 \mathrm{U} / \mathrm{mL}$.

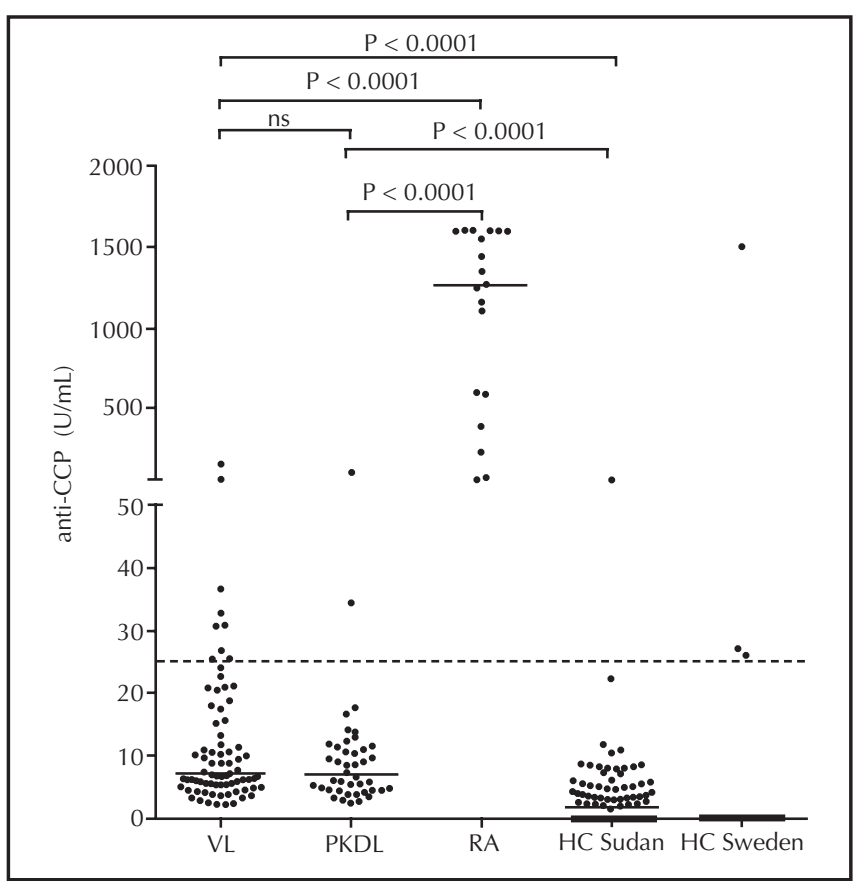

Figure 3

Anti-CCP levels in the different groups. The dotted lines represent the cut-off $(25 \mathrm{Eq} / \mathrm{mL})$ as described by the producer, and solid lines show the median in each group. 
Table 1

Correlations between levels of RF, anti-CCP, and CIC in the different groups of investigated subjects

\begin{tabular}{|c|c|c|c|}
\hline & RF vs. IC & RF vs. anti-CCP & IC vs. anti-CCP \\
\hline $\begin{array}{l}\mathrm{VL+PKDL} \\
(\mathrm{n}=116)\end{array}$ & $\begin{array}{l}0.1985 \\
(P=0.0327)\end{array}$ & $\begin{array}{l}-0.0087 \\
(P=0.9260)\end{array}$ & $\begin{array}{l}0.5598 \\
(\mathrm{P}<0.0001)\end{array}$ \\
\hline$V L(n=74)$ & $\begin{array}{l}0.1225 \\
(P=0.2983)\end{array}$ & $\begin{array}{l}-0.0394 \\
(P=0.7388)\end{array}$ & $\begin{array}{l}0.6586 \\
(\mathrm{P}<0.0001)\end{array}$ \\
\hline PKDL $(n=42)$ & $\begin{array}{l}0.1055 \\
(\mathrm{P}=0.5061)\end{array}$ & $\begin{array}{l}0.0133 \\
(\mathrm{P}=0.9334)\end{array}$ & $\begin{array}{l}0.0687 \\
(\mathrm{P}=0.6655)\end{array}$ \\
\hline $\begin{array}{l}\text { CCP-positive } \\
\text { RA patients } \\
(\mathrm{n}=19)\end{array}$ & $\begin{array}{l}0.6398 \\
(P=0.0032)\end{array}$ & $\begin{array}{l}0.2638 \\
(P=0.2751)\end{array}$ & $\begin{array}{l}0.3395 \\
(P=0.1550)\end{array}$ \\
\hline $\begin{array}{l}\text { Sudanese } \\
\text { healthy } \\
\text { controls } \\
(\mathrm{n}=93)\end{array}$ & $\begin{array}{l}-0.0735 \\
(P=0.4836)\end{array}$ & $\begin{array}{l}-0.0031 \\
(P=0.9766)\end{array}$ & $\begin{array}{l}-0.0204 \\
(P=0.9766)\end{array}$ \\
\hline $\begin{array}{l}\text { All groups } \\
\text { (n = 228) }\end{array}$ & $\begin{array}{l}0.1966 \\
(P=0.0029)\end{array}$ & $\begin{array}{l}0.3008 \\
(P<0.0001)\end{array}$ & $\begin{array}{l}-0.0153 \\
(P=0.8183)\end{array}$ \\
\hline
\end{tabular}

The levels of anti-CCP among VL patients correlated well with the IC levels $(r=0.6586, P<0.0001-$ Table 1$)$. In the anti-CCP positive RA group, no association was found between IC levels and anti-CCP. To rule out the possibility that anti-CCP positivity was due to cross reactions with IC, or that the CCPreactivity might be primarily bound to IC, we adsorbed $\mathrm{Clq}$ binding IC from sera and evaluated CCP reactivity afte wards. This procedure did not diminish the ant-CCP reactivity in either the VL group or among anti-CCP positive RA patients. The median anti-CCP reactivity left after IC adsorption was
$97 \%$ in all groups, range: VL $61 \%-175 \%$, RA $77 \%-107 \%$, PKDL $85 \%-102 \%$ (data not shown).

We then analysed the citrulline specificity among anti$\mathrm{CCP}$ positive patients using a control plate containing noncitrullinated cyclic peptides as target antigen; data are shown in Figure 4. Among the anti-CCP positive samples in the VL group there was no difference in reactivity against $\mathrm{CCP}$ and the non citrullinated control peptide (Figure 4A). The same pattern was found for the two anti-CCP positive PKDL patients (Figure 4B). This non-citrulline specific reactivity was in strict contrast to the anti-CCP positiv Sudanese RA patients whose anti-CCP reactivity was specific for $\mathrm{CCP}$ and with very low reactivity with the arginine containing control peptides $(\mathrm{P}<0.0001$; Figure 4C).

\section{DISCUSSION}

In this study we found that sera from Leishmania infected patients were often RF positive, had elevated levels of CIC, and that a substantial amount (11.4\%) showed reactivity toward CCP. However, contrary to what was seen in Sudanese RN sera, the CCP reactivity was not restricted to citrullinecontaining peptides, as there was an equal reactivity against cyclic arginine-containing control peptides, both in patients with the acute form of VL as well as with the post-treatment PKDL form.

One small study has earlier demonstrated anti-CCP2 reactivity in a small group of ten Brazilian patients infected with the parasite Leishmania major. ${ }^{30}$ However, citrulline
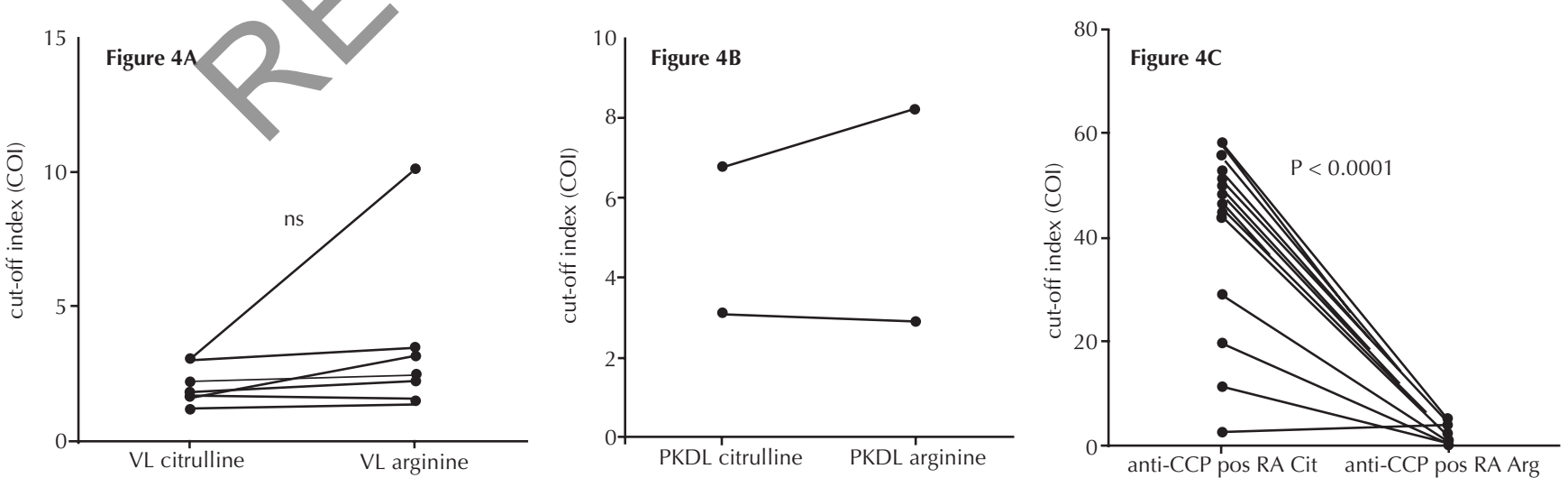

Figure 4

Citrulline specificity among anti-CCP positive patients and among (A) VL; (B) PKDL; and (C) Sudanese RA patients. Results are calculated as cut-off index (COI): observed arginine $\mathrm{OD}_{450} /$ citrulline cut-off $\mathrm{OD}_{450}$. 
dependency of CCP-reactive sera was not evaluated in this study. We have now extended these studies to encompass a larger cohort of Sudanese patients infected with $L$. donovani, both the acute VL form and the post-treatment PKDL form not appearing in South America. We have shown that patients with both diagnoses might have anti-CCP2 reactivity that is directed to the cyclic peptide backbone without the need for citrullination of arginine residues. This was in contrast to Sudanese RA patients who showed a strict dependency for citrullination of arginine residues to yield high anti-CCP2 reactivity.

Besides our study, only two reports of ACPA reactivity in patients with non-rheumatic conditions have investigated their sera using proper arginine-containing control ELISA wells. The study by Vannini et al. ${ }^{24}$ on autoimmune hepatitis type I patients used proper controls for the commercial but proprietary CCP2 assay, which did not disclosed the peptide composition to the scientific community, as well as for the publicly described CCP1 peptide, ${ }^{5}$ and showed that whereas the majority ( $87 \%$ ) of CCP positive sera from rheumatological patients with other diagnoses than RA were citrulline specifie, this was the case only for half of the investigated hepatitis sera. In a study of tuberculosis by Kakumanu et al. ${ }^{2}$ the reactivity against the CCP1 peptide was shown to be citulline specific in $94 \%$ of RA sera and in $22 \%$ of sera from pulmonary tuberculosis patients. The authors also showed that soluble CCP1 peptide inhibited reactivity with RA sera but not with TB sera; an investigation that we could not repeat with the proprietary $\mathrm{CCP} 2$ reagents.

Even though the CCP2 test is the most commonly used ACPA test in clinical diagnostic settings, the proprietary and secluded nature of the C 2 antigen represents an obvious hurdle in studies of non rheumatic conditions, such as autoimmune hepatitis ${ }^{24}$ and uberculosis, ${ }^{21}$ where the use of proper controls have shown the CCP reactivities to be much less citrulline-dependent than in parallel studies of RA patients. The citrulline dependency of ACPA reactivity has been unequivocally proofed in numerous studies of RA patients. The fact that only a small minority of commercial ACPA tests are designed with proper control wells with non-citrullinated antigens is therefore no major drawback in clinical practice. When ACPA are shown in non-rheumatic conditions, the findings should however preferably be investigated concerning the citrullinedependency of the reactivity.

Our finding that CCP reactivity in VL patients was not restricted to citrulline argues that anti-CCP reactivity is more an effect of extensive inflammation and immune activation than a sign of shared pathogenic characteristics with anti-CCP positive arthritis. In RA, anti-CCP reactivity shows a bimodal distribution with mostly either totally negative or very high positive levels, where the anti-CCP positive patient group is defined by certain genetic characteristics and impact of trigger factors, notably smoking. ${ }^{31}$ In the present study the mean anti-CCP reactivity among positive subjects was $49 \mathrm{U} /$ $\mathrm{mL}$, representing 1.96 time the cut-off value; data on low positive anti-CCP reactivity is in agreement with the findings in Brazilian leishmaniasis. ${ }^{30}$ This is in stark contrast to Swedish anti-CCP positive RA patient, presenting a mean level of $1128 \mathrm{U} / \mathrm{mL}$ (45.1 times the cut-off) using the same anti-CCP test. ${ }^{18}$ This hypothesis is also supported by the fact that the CCP2 reactivity in VI and PKDL patients showed a continuum between the an $\mathrm{CCP} 2$ positive sera and the "negative" interval below the cut-off, whereas anti-CCP negative Sudanese controls showed lower reactivity (Figure 3). This is also in accordance with our experience of Swedish RA patients, where the anti-CCP negative subjects mostly show very low reactivity within the negative area (unpublished observations). Although it seems that some infections might yiel falsely positive anti-CCP, there is a possibility that inrections really are associated with the appearance of ACPA, and that the citrulline-specificity of the ACPA response might develop over time. One example is immunity to the bacteria Porphyromonas gingivalis associated with periodontitis. It has been shown that $P$. gingivalis is able to citrullinate proteins suggesting that $P$. gingivalis-mediated citrullination provides a molecular mechanism for generating antigens driving the autoimmune response against ACPA in RA..$^{32,33}$

An intriguing finding is that two groups of infections, where a non-citrulline specific and non-arthritis-associated ACPA response has been reported, represent agents localizing intracellularly in tissue macrophages. Both Leishmania parasites, ${ }^{30}$ as well as tuberculosis ${ }^{21,25}$ represent intracellular infections in tissue macrophages. The findings of ACPA responses in hepatitis $\mathrm{C},,^{22,23,34}$ where the infection primarily resides in the hepatocytes, might not seem in accordance with such a hypothesis. Although, one should remember the ongoing debate on whether macrophages, in addition to hepatocytes, are infected by hepatitis $\mathrm{C}$ virus as reviewed in Heydtmann.$^{35}$ Also, the autoimmune hepatitis type 1, where arthritis-independent ACPA reactivity has been shown, ${ }^{24}$ is associated with macrophage activation both in the early ${ }^{36}$ and later fibrotic stages. ${ }^{37}$

In this study we have shown that Sudanese patients infected with the L. donovani parasite show serological similarities with RA patients from Sudan and elsewhere. Besides increased levels of CIC and RF, we have for the first time shown reactivity to 
the ACPA target CCP2, a finding commonly regarded as highly specific for RA. This ACPA reactivity is, contrary to what is seen in RA patients, not dependent on citrullination of the antigenic target, and might tentatively be associated with heavy activation of the macrophage system. Our results, as well as earlier results $^{21,24}$ stress the importance of including appropriate assay controls when defining ACPA reactivity in new patient groups, especially in non-rheumatic patient cohorts.

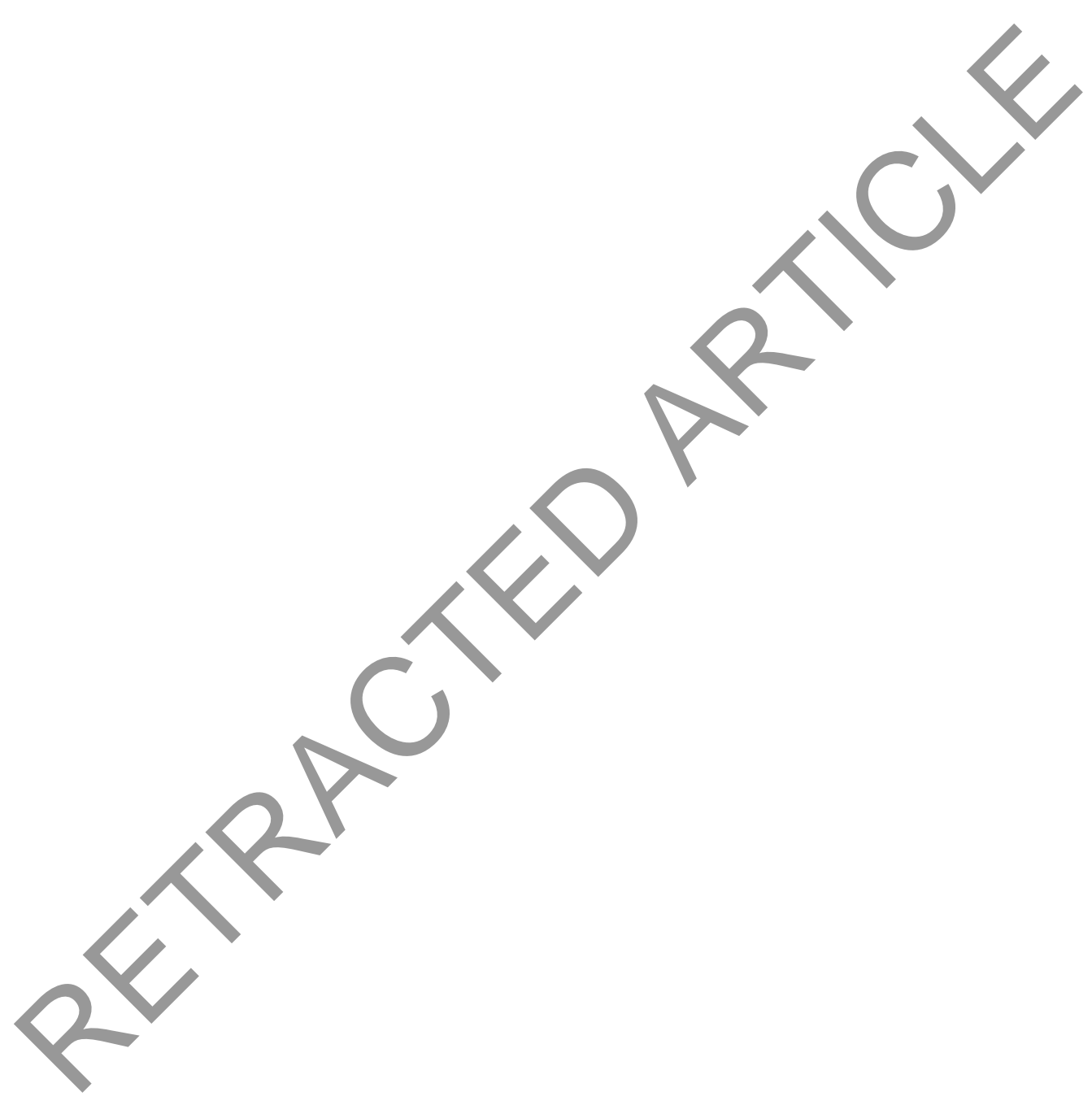




\section{REFERENCES}

\section{REFERÊNCIAS}

1. Winchester RJ, Agnello V, Kunkel HG. Gamma globulin complexes in synovial fluids of patients with rheumatoid arthritis. Partial characterization and relationship to lowered complement levels. Clin Exp Immunol 1970; 6(5):689-706.

2. Estes D, Christian CL. The natural history of systemic lupus erythematosus by prospective analysis. Medicine (Baltimore) 1971; 50(2):85-95.

3. Bunim JJ, Buchanan WW, Wertlake PT, Sokoloff L, Bloch KJ, Beck JS et al. Clinical, pathologic, and setologic studies in Sjoegren's syndrome; Combined Clinical Staf Conference at the National Institutes of Health. Ann Intern Med 964; 61:509-30.

4. Dresner E, Trombly P. The latex-fixation reaction in nonrheumatic diseases. N Engl J Med 1959. 261.981-8.

5. Schellekens GA, Visser H, de-Jong BA, van den Hoogen FH, Hazes JM, Breedveld (C et al. The diagnostic properties of rheumatoid arthrifis antibodies recognizing a cyclic citrullinated peptide. Arthri is Rheum 2000; 43(1):155-63.

6. Mathsson L_Lampa Mullazehi M, Rönnelid J. Immune complexes from rheumatoid arthritis synovial fluid induce FcgRIIa dependent and rheumatoid factor correlated production of tumour necrosis factor-alpha by peripheral blood mononuclear cells. Arthritis Res Ther 2006: 8(3):R64.

7. New urk MM. Rheumatoid factors: host resistance or autoimmunity? Clin Immunol 2002; 104(1):1-13.

8. Dörner T, Egerer K, Feist E. Burmester GR. Rheumatoid factor revisited. Curr Opin Rheumatol 2004; 16(3):246-53.

Carvalho EM, Andrew BS, Martinelli R, Dutra M, Rocha H. Circulating immune complexes and rheumatoid factor in schistosomiasis and visceral leishmaniasis. Am J Trop Med Hyg 1983; 32(1):61-8.

10. Galvão-Castro B, Sá Ferreira JA, Marzochi KF, Marzochi MC, Coutinho SG, Lambert PH. Polyclonal B cell activation, circulating immune complexes and autoimmunity in human American visceral leishmaniasis. Clin Exp Immunol 1984; 56(1):58-66.

11. Kager PA, Hack CE, Hannema AJ, Rees PH, von dem Borne AE. High C1q levels, low $\mathrm{C} 1 \mathrm{~s} / \mathrm{C} 1 \mathrm{q}$ ratios, and high levels of circulating immune complexes in kala-azar. Clin Immunol Immunopathol 1982; 23(1):86-93.

12. Kharazmi A, Rezai HR, Fani M, Behforouz NC. Evidence for the presence of circulating immune complexes in serum and C3b and C $3 \mathrm{~d}$ on red cells of kala-azar patients. Trans R Soc Trop Med Hyg 1982; 76(6):793-6.

13. Makni S, Ayed K, Ben Said M, Ben Rachid MS. Study of circulating immune complexes during the evolution of visceral Mediterranean leishmaniasis. Ann Trop Med Parasitol 1989; 83(4):349-55.

14. Pearson RD, deAlencar JE, Romito R, Naidu TG, Young AC, Davis JS 4th. Circulating immune complexes and rheumatoid factors in visceral leishmaniasis. J Infect Dis 1983; 147(6):1102.

15. Sehgal S, Aikat BK, Pathania AG. Immune complexes in Indian kala-azar. Bull World Health Organ 1982; 60(6):945-50.

16. Elshafie A, Ahlin E, Mathsson L, Elghazali G, Rönnelid J. Circulating immune complexes (IC) and IC-induced levels of GM-CSF are increased in Sudanese patients with acute visceral Leishmania donovani infection undergoing sodium stibogluconate treatment: implications for disease pathogenesis. J Immunol 2007; 178(8):5383-9. 
17. Makrygiannakis D, af Klint E, Lundberg IE, Löfberg R, Ulfgren AK, Klareskog L et al. Citrullination is an inflammation-dependent process. Ann Rheum Dis 2006; 65(9):1219-22.

18. Rönnelid J, Wick MC, Lampa J, Lindblad S, Nordmark B, Klareskog L et al. Longitudinal analysis of anti-citrullinated protein/peptide antibodies (anti-CP) during 5-year follow-up in early rheumatoid arthritis: anti-CP status is a stable phenotype that predicts worse disease activity and greater radiological progression. Ann Rheum Dis 2005; 64(12):1744-9.

19. Kroot EJ, de Jong BA, van Leeuwen MA, Swinkels H, van den Hoogen FH, van't Hof $\mathrm{M}$ et al. The prognostic value of anticyclic citrullinated peptide antibody in patients with recent-onset rheumatoid arthritis. Arthritis Rheum 2000; 43(8):1831-5.

20. Kallberg H, Padyukov L, Plenge RM, Ronnelid J, Gregersen PK, van der Helm-van Mil AH et al. Gene-gene and gene-environment interactions involving HLA-DRB1, PTPN22, and smoking in two subsets of rheumatoid arthritis. Am J Hum Genet 2007; 80(5):867-75.

21. Kakumanu P, Yamagata H, Sobel ES, Reeves WH, Chan EK, Satoh M. Patients with pulmonary tuberculosis are frequently positive for anti-cyclic citrullinated peptide antibodies, but their sera also react with unmodified arginine-containing peptide. Arthritis Rheum 2008; 58(6):1576-81.

22. Bassyouni IH, Ezzat Y, Hamdy S, Talaat RM. Clinical significance of anti-cyclic citrullinated peptide antibodies in Egyptian patients with chronic hepatitis $\mathrm{C}$ virus genotype IV infection. Clin Chem Lab Med 2009; 47(7):842-7.

23. Orge E, Cefle A, Yazici A, Gurel-Polat N, Hulagu S. The positivity of rheumatoid factor and anti-cyclic citrullinated peptide an foody is non-arthritic patients with chronic hepatitis $\mathrm{C}$ infection. Rheumatol Int 2010; 30(4):485-8.

24. Vannini A, Cheung K, Fusconi M, Stammen-Vogelzangs J, Dlenth JP, Dall'Aglio AC et al. Anti-cyclic citrullinated peptde positivity in non-rheumatoid arthritis disease samples: citrulline-dependent or not? Ann Rheum Dis 2007; 66(4):511-6

25. Elkayam O, Segal R, Lidgi M, Caspi D. Positive anti-cyclic citrullinated proteins and rheumatoid lactor during active lung tuberculosis. Ann Rheum Dis 2006; 65(8):1110-2.

26. Mathsson L, Mullazehi M,Wick MC Sjöberg O, van Vollenhoven R, Klareskog L et al. Antibodies agamst citrullinated vimentin in rheumatoid arthritis: higher sensitivity and extended prognostic value concerning future adiographic progression as compared with antibodies against cyclic cit ullinated peptides. Arthritis Rheum 2008; 58(1):36-45.
27. Mahdi H, Fisher BA, Kallberg H, PlantD, Malmström V, Rönnelid J et al Specific interaction between genotype, smoking and autoimmunity to citrullinated alpha-enolase in the etiology of rheumatoid arthritis. Nat Genet 2009; 41(12):1319-24.

28. Hoogstra H, Heyneman D. Leishmaniasis in Sudan Republic. Final epidemiologic report. Am J Trop Med Hyg 1969; 18:1091-7.

29. Arnett FC, Edworthy SM, Block DA, McShane DJ, Fries JF, Cooper NS et al. The American Rheumatism Association 1987 revised criteria for the classification of rheumatoid arthritis. Arthritis Rheum 1988; 31(3):315-24.

30. Atta AM, Carvalho EM, Jerônimo SM Sousa Atta ML. Serum markers of rheumatoid arthritis în visceral le hmaniasis: rheumatoid factor and anti-cyclic citrullinated peptide antibody. J Autoimmun 2007; 28(1):55-8.

31. Klareskog L, Stolt P Lundberg K, Källberg H, Bengtsson C, Grunewald $\mathrm{J}$ et al. A new model for an etiology of rheumatoid arthritis: smoking may trigger HLA-DR (shared epitope)-restricted immune reactions to auto-antigens modified by citrullination. Arthritis Rheum 2006; 54(1):38-46.

32. Lundberg Kinloch A, Fisher BA, Wegner N, Wait R, Charles Pet al. Antibodies to citrullinated alpha-enolase peptide 1 are specific for rheu hatoid arthritis and cross-react with bacterial enolase. Arthritis Rheun 2008; 58(10):3009-19.

33. Wegner N, Wait R, Sroka A, Eick S, Nguyen KA, Lundberg K et al. Peptidylarginine deiminase from Porphyromonas gingivalis citrullinates human fibrinogen and alpha-enolase: Implications for autoimmunity in rheumatoid arthritis. Arthritis Rheum 2010; 62(9):2662-72.

34. Wener MH, Hutchinson K, Morishima C, Gretch DR. Absence of antibodies to cyclic citrullinated peptide in sera of patients with hepatitis $\mathrm{C}$ virus infection and cryoglobulinemia. Arthritis Rheum 2004; 50(7):2305-8.

35. Heydtmann M. Macrophages in hepatitis B and hepatitis $C$ virus infections. J Virol 2009; 83(7):2796-802.

36. Tsikrikoni A, Kyriakou DS, Rigopoulou EI, Alexandrakis MG, Zachou K, Passam F et al. Markers of cell activation and apoptosis in bone marrow mononuclear cells of patients with autoimmune hepatitis type 1 and primary biliary cirrhosis. J Hepatol 2005; 42(3):393-9.

37. Heymann F, Trautwein C, Tacke F. Monocytes and macrophages as cellular targets in liver fibrosis. Inflamm Allergy Drug Targets 2009; 8(4):307-18. 
In the December 2011 issue, the Brazilian Journal of Rheumatology published the article: "Anticitrullinated peptide antibodies and rheumatoid factor in Sudanese patients with Leishmania donovani infection" by E. Ahlin, A. Elshafei, M. Nur, S.H. El Safi, R. Johan, and G. Elghazali. [Revista Brasileira de Reumatologia 51, 6 (2011)]. On January 2012, the BJR received a claim from one of the authors, questioning the authorship of the corresponding author, and informed that the article was under submission to another journal, by E. Ahlin, A.I. Elshafie, M.A.M. Nur, and J. Ronnelid. This submission is on hold, the authors were all informed of the claim and the case was submitted to the Committee on Publication Ethics (COPE), which gave some recommendations. The investigation has not yet reached a conclusion. Pending the results of the investigations, BJR is publishing this Editorial Expression of Concern to alert our readers to the fact that serious questions have been raised about the authorship in the Afhlin et al. paper.

Paulo Louzada-Junior and Max Victor Carioca Freitas

Editors-in-chief - Revista Brasileira de Reumatologia 